J. Clin. Chem. Clin. Biochem.

Vol. 23, 1985, pp. $691-695$

\title{
The Preparation and Use of a Carrier-Bound Acceptor for the Determination of Sialyl Transferase Activity in Serum
}

\author{
By U. Ganzinger and F.M. Unger \\ Sandoz Forschungsinstitut Wien, Austria
}

(Received January 3/May 2, 1985)

Summary: Agarose-bound asialofetuin functions as an insoluble sialyl group acceptor in a simplified assay for sialyl transferase (CMP-neuraminate: $D$-galactosyl-glycoprotein $\mathrm{N}$-acetylneuraminyl transferase; EC 2.4.99.1) in serum. Since sialyl transferase levels in serum are elevated in a large number of malignant conditions, the simplified assay is of use for clinical monitoring in tumour therapeutic programmes.

Bereitung und Anw'endung eines trägergebundenen Akzeptors für die Bestimmung der Sialyltransferase-Aklivilät im Serum

Zusammenfassung: Kovalent an Agarose gebundenes Asialofetuin dient als unlöslicher N-Acetylneuraminsäure-Akzeptor in einer vereinfachten Methode für die Bestimmung der Sialyltransferase im Serum (CMPNeuraminat: $D$-galactosyl-glycoprotein $\mathrm{N}$-acetylneuraminyltransferase, EC 2.4.99.1). Nachdem die Sialyltransferase-Aktivität im Serum bei einer Vielzahl maligner Erkrankungen erhöht ist, eignet sich die hier beschriebene Methode insbesondere für die Enzymbestimmung im Rahmen von Verlaufskontrollen.

\section{Introduction}

Recently, a number of reports have appeared describing augmented levels of sialyl transferase (EC 2.4.99.1) $(1,2)$ in sera from cancer patients. In this context, others and ourselves $(3-5)$ have demonstrated significant correlations between augmented serum sialyl transferase activity and tumour mass, stage of disease, and extent of metastatic involvement. In the course of these studies, we have found that the results obtained by the classical serum sialyl transferase assay, based on incorporation of radioactive $\mathrm{N}$-acetylneuraminic acid (NeuAc) into glycoprotein, followed by precipitation of glycoprotein with acid (16), are subject to unduly large variations, and are thus of limited value. Similar problems have been noted by others (7). For this reason, we have developed a simplified assay procedure for serum sialyl transferase based on the use of asialofetuin as a carrier-bound, insoluble sialyl group acceptor. This test affords results sufficiently reliable to be employed by clinical laboratory staff in large series of determinations.

\section{Materials and Methods}

\section{Reagents}

Sepharose 4B (Pharmacia Fine Chemicals A. B., Uppsala, Sweden); fetuin (GIBCO Diagnostics, Madison, WI, 53713); cyanogen bromide (Serva Feinchemikalien, Heidelberg, WestGermany); Cytidine-5'-monophospho[ $\left[{ }^{14} \mathrm{C}\right] \mathrm{N}$-acetylneuraminic acid (CMP-NeuAc), spec. act., 5.5-11.0 GBq/mmol; sodium boro- $\left[{ }^{3} \mathrm{H}\right]$ hydride, spec. act., $185-740 \mathrm{GBq} / \mathrm{mmol}$; (The Radiochemical Centre, Amersham U. K.); galactose oxidase (ICN Biochemicals Inc., Cleveland OH, USA), and Insta-gel (Packard Instrument Comp., Downers Grove, IL, USA). All other chemicals used were of the purest grade available.

\section{Sialyl transferase}

In all experiments, the source of the enzyme was human serum obtained from whole blood. Blood was taken either from cancer patients with proven tumours or from healthy volunteers. Samples from individuals, or pooled material, were routinely stored at $-20^{\circ} \mathrm{C}$ for up to 1 month or, for specific experiments, under different conditions as indicated in the text.

\section{Preparative procedures}

Asialofetuin was prepared by mild acid hydrolysis of fetuin, following the procedure of Spiro et al. (8). Tritium-labelled asialofetuin ( $\left[{ }^{3} \mathrm{H}\right]$ asialofetuin) was prepared from asialofetuin 
by oxidation of terminal galactosyl residues, catalysed by galactose oxidasc, followed by reduction with sodium baro$\left[{ }^{3} \mathrm{H}\right]$ hydride, using essentially the method described by Morell ct al. (9). Cyanogen-bromide activation of Sepharose 4B, and coupling of asialofetuin, were performed as described by $\mathrm{Cu}$ atrecasas et al. (10), using $12.5 \mathrm{~g}$ of solid cyanogen bromide $(\mathrm{CNBr})$ for $100 \mathrm{~g}$ wet weight of Sepharose 4B. For covalent coupling, $4 \mathrm{mg}$ asialofetuin were used per $1 \mathrm{~g}$ of cyanogen bromide-activated Sepharose 4B. After removing the reagents of the coupling reaction, the insoluble sialyl acceptor-complex (asialofetuin-Sepharose 4B) was suspended in the incubation buffer of the enzymatic reaction $(0.01 \mathrm{~mol} / \mathrm{l}$ Tris- $\mathrm{HCl} \mathrm{pH} 7.3$ containing $0.005 \mathrm{~mol} / 1 \mathrm{MnCl}_{2}$ ). The final concentration was $7 \mathrm{ml}$ of sedimented acceptor-complex in a total buffer volume of $10 \mathrm{ml}$. This suspension was stored at $4^{\circ} \mathrm{C}$.

\section{Protein determinations}

Protein determinations were performed according to Lowry et al. (11). Protein bound to Sepharose 4B was estimated according to Koelsch et al. (12).

Assay procedures for serum sialyl transferase using a soluble acceptor

A slightly modified procedure of Bosman et al. was used (6). Tris-HCl-buffer, $(0.01 \mathrm{~mol} / \mathrm{l} ; \mathrm{pH} 7.3)(100 \mu \mathrm{l})$, containing 0.005 $\mathrm{mol} / \mathrm{l}$ manganese chloride, and asialofetuin (15 $\mu \mathrm{g}$ protein), were mixed with serum samples $(100 \mu l)$ and $\mathrm{CMP}-\left[{ }^{14} \mathrm{C}\right] \mathrm{NeuAc}$ solution (ca. $0.5 \mathrm{nmol}$ in $5 \mu \mathrm{l}$, spec. act. $5.5-11.0 \mathrm{GBq} / \mathrm{mmol}$ ). The mixtures were incubated at $37^{\circ} \mathrm{C}$ for $30 \mathrm{~min}$. Following incubation, the soluble radioactivity was removed either by precipitating the glycoprotein with phosphotungstic acid, or by passage of the reaction mixture over small ion-exchange columns (Dowex $1 \mathrm{X} 8 \mathrm{OH}^{-}$-form, $5-15 \mathrm{~mm}$ ) (13).
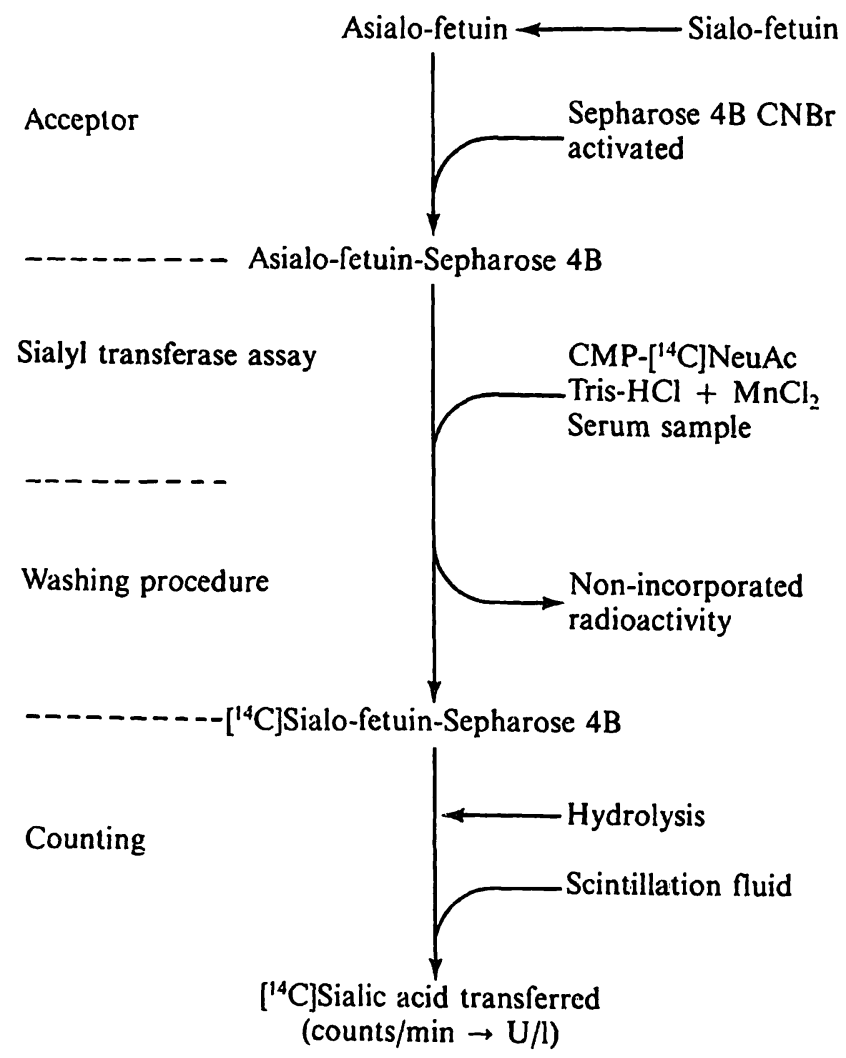

Fig. 1. Schematic diagram for the procedure of the serum sialyl transferase determination.

\section{Results}

Properties of the insoluble asialofetuin-Sepharose 4B-acceptor complex

\section{Optimal ratio of asialofetuin to Sepharose $4 B$}

Maximal acceptor activity was robserved when 25.4 $\mathrm{mg}$ of asialofetuin protein per $1 \mathrm{~g}$ (dry weight) of CNBr-activated Sepharose 4B was used in the coupling reaction, resulting in $7.8 \mu \mathrm{g}$ protein covalently bound per $1 \mathrm{mg}$ of acceptor-complex (dry weight). When the amount of asialofetuin bound to 1 mg (dry weight) of $\mathrm{CNBr}$-activated Sepharose 4B exceeded 50 $\mu \mathrm{g}$ (protein), the subsequent enzymatic transfer of sialyl groups to the acceptor was significantly impeded.

\section{Stability of the insoluble acceptor}

Samples of $\left[{ }^{3} \mathrm{H}\right]$ asialofetuin-Sepharose 4B-complex and of non-radioactive asialofetuin-Sepharose $4 \mathrm{~B}$ were suspended in the incubation buffer and stored at $4{ }^{\circ} \mathrm{C}$ or at room temperature. $1,2,3$, and 6 months after preparation, the amounts of bound protein were determined by counting radioactivity, and by colorimetric assay of asialofetuin (12). The acceptor-complex, when stored at $4{ }^{\circ} \mathrm{C}$, is stable for 2 months. During the third month after preparation a fraction of 0.8 , and, after 6 months of 0.65 remains. After two months at room temperature, the acceptor-complex had lost a fraction of 0.2 , and within 6 months a fraction of 0.35 , of the protein originally bound.

\section{Assay procedure for serum sialyl transferase using the insoluble sialyl group acceptor}

The procedure for the serum sialyl transferase determination is schematically depicted in figure 1.

Asialofetuin-Sepharose 4B suspension $(100 \mu \mathrm{l}$, corresponding to $1.8 \mathrm{mg}$ dry weight, with an asialofetuin content of $14 \mu \mathrm{g}$ protein), CMP-[14 C]NeuAc $(5 \mu \mathrm{l}$, spec. act. $5.5-11.0 \mathrm{GBq} / \mathrm{mmol})$ and the serum samples $(100 \mu \mathrm{l})$ were mixed in plastic tubes and incubated in a $37^{\circ} \mathrm{C}$ water bath for $30 \mathrm{~min}$ with gentle shaking. Subsequently, the soluble radioactivity was removed by washing the acceptor complex with four times $1 \mathrm{ml}$ each of $3 \mathrm{~mol} / \mathrm{l}$ guanidinum chloride solution. This washing solution is preferable to water or $1 \mathrm{~mol} / \mathrm{l}$ sodium chloride, as washing with the latter resulted in a higher proportion of unspecifically bound radioactivity in the beads. Care was taken during removal of the supernatants after each sedimentation. Following the final wash, the sedimented 
beads were dissolved by adding $2 \mathrm{~mol} / \mathrm{l}$ sulphuric acid $(1 \mathrm{ml})$ and allowing to stand at $80^{\circ} \mathrm{C}$ for $20 \mathrm{~min}$. After cooling, the clear, colourless solutions were quantitatively transferred into counting vials containing Insta-gel ${ }^{\circledR}(10 \mathrm{ml})$. A somewhat lower counting efficiency was observed when the acceptor complex, following the final wash, was quantitatively transferred into a scintillation vial, dispersed in a mixture of water and Insta-gel ${ }^{\circledR}$, and counted. Radioactivity was determined using a Tri-Carb liquid scintillation counter, and was converted ${ }^{1}$ ) into $\mu \mathrm{mol} / \mathrm{min}$ of serum sialyl transferase per litre of serum.

\section{Incubation conditions}

The dependence of the binding of NeuAc to carrierbound asialofetuin on the duration and temperature of the incubation is shown in figure 2 . When the reaction mixtures are incubated at $37^{\circ} \mathrm{C}$, a linear increase of radioactivity becoming bound is observed for up to $150 \mathrm{~min}$, and at room temperature, for up to $180 \mathrm{~min}$. Thereafter, slightly less NeuAc is found incorporated into the glycoprotein acceptor. Serum sialyl trasferase is apparently denatured by heating to more than $56^{\circ} \mathrm{C}$.

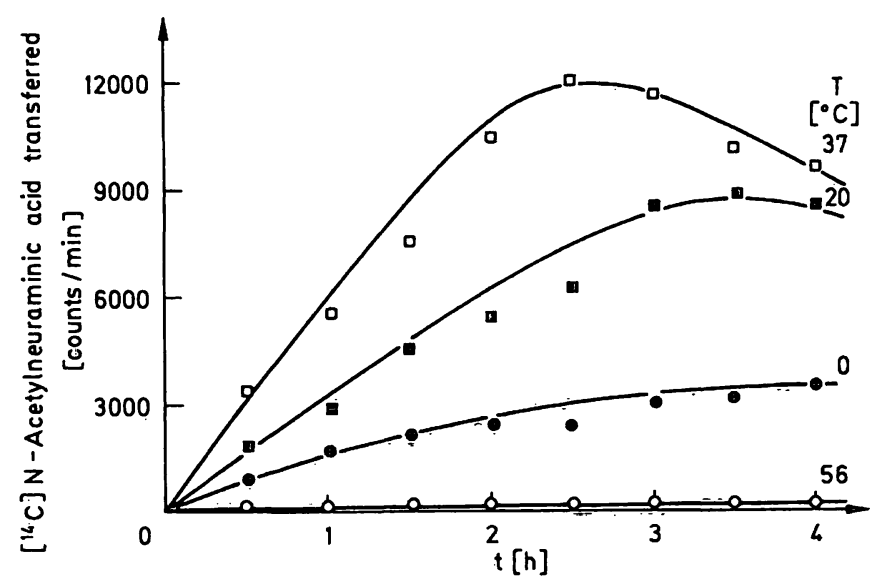

Fig. 2. Dependence of the amounts of $\mathrm{N}$-acetylneuraminic acid incorporated into carrier-bound asialofetuin on the duration and temperature of incubation.

To determine the $\mathrm{pH}$ optimum of the serum sialyl transferase reaction, the acceptor complex was suspënded in various bufferis covering the $\mathrm{pH}$ range from 6.5 to 8.0. A $0.01 \mathrm{~mol} / \mathrm{l}$ Tris- $\mathrm{HCl}$ buffer $(\mathrm{pH} \mathrm{7.3)}$ was found optimal. In $0.01 \mathrm{~mol} / 1 \mathrm{Tris}$-maleate, or sodium cacodylate buffers, less NeuAc became incorporated at all $\mathrm{pH}$ values tested. Furthermore, the presence of manganese chloride is necessary for op-

') One unit of serum sialyltransferase is defined as the amount of enzyme which catalyses the transfer of $1 \mu \mathrm{mol} / \mathrm{min}$ of $\left[{ }^{14} \mathrm{C}\right] \mathrm{NeuAc}$ into asialofetuin-Sepharose 4B-complex under the conditions described above. timal enzyme activity. When magnesium chloride was used instead of manganese chloride, a reduction in enzyme activity by a factor of ca. 0.85 was observed. In the absence of divalent metal ions, the rate of incorporation was lower by a factor of about 0.75 .

Serum sialyl transferase activity decreases by a fraction of ca. 0.2 when serum samples are kept at room temperature for $24 \mathrm{~h}$. Thus, after blood collection, clotting and centrifugation, samples should promptly be cooled to $-20^{\circ} \mathrm{C}$. At this temperature, the sera can be stored for 3 months without significant loss of enzyme activity. On storage for 6 months, a decrease of up to one half is observed. The addition of blood clotting inhibitors to whole blood results in decreased enzyme activity of plasma samples (ca. one half using heparin and 0.4 using sodium citrate).

Variations of the glycoprotein content in individual serum samples, frequently associated with various pathological conditions, have practically no influence on the measured serum sialyl transferase activities when the insoluble acceptor-complex assay system is used. Practically all of the endogenous acceptors to which radioactive sialic acid may be transferred in the enzymatic reaction are removed during the washing procedure, as is the non-incorporated radioactivity. Thus, it is not necessary to run parallel blanks, since the amount of radioactivity unspecifically bound to the beads is very low and constant.

Accuracy and reproducibility of serum sialyl transferase determinations

Pipetting of the acceptor from suspensions containing varying ratios of sedimented resin to buffer results in a variation coefficient of $5.1 \pm 1.5 \%$ with respect to the amount of acceptor complex. Therefore, the suspensions were gently stirred during pipetting. When a serological pipette was used to deliver the suspension of the insoluble acceptor ( 6 consecutive experiments with 3 parallel determinations each), a variation coefficient of $4.3 \%$ for the dry weight and $2.2 \%$ for the radioactivity of $\left[{ }^{3} \mathrm{H}\right]$ asialofetuinSepharose was calculated. However, when a constant delivery, disposable tip micropipette was used, the variation coefficient was found to be ca. $30 \%$, both with respect to dry weight and radioactivity.

To locate further potential errors due to incorrect handling of this assay system, the amount of the acceptor complex and sialic acid donor (CMP$\left.\left[{ }^{14} \mathrm{C}\right] \mathrm{Neu} A \mathrm{Ac}\right)$, and the incubation time were varied according to the "central composible rotable design" 
(14). With the data obtained from 6 cancer patients and 6 controls, two different equations were formulated.

$y_{n}=50.5+5.8\left(\frac{x-100}{5}\right)$

(residual mean square $=19.9$ )

$y_{c}=77.9+7.3\left(\frac{z-100}{5}\right)+7.3\left(\frac{x-100}{5}\right)$

(residual mean square $=26.8$ )

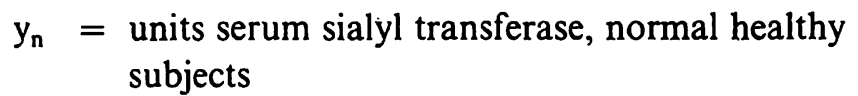

$\mathrm{y}_{\mathrm{c}}=$ units serum sialyl transferase, cancer patients

$\mathrm{x}=\%$ variation in the amount of acceptor complex

$\mathrm{z}=\%$ variation in the time of incubation $(\mathrm{min})$

A variation of $\pm 20 \%$ in the amount of substrate (CMP- $\left.\left[{ }^{14} \mathrm{C}\right] \mathrm{NeuAc}\right)$ has no influence on the serum sialyl transferase activity measured. Decreasing or increasing the amount of acceptor complex causes a proportional change of the serum sialyl transferase activity. Interestingly, extension of the incubation period results in an increased incorporation of radioactivity, which is 1.10 times greater for sera from cancer patients than for control sera.

To demonstrate the reliability of the serum sialyl transferase determinations in a practical situation, serum sialyl transferase was determined daily in 6 healthy controls ( 4 parallels) over a period of five consecutive days. Within this time, the individual enzyme levels were found to vary in the range of 2.31 $\pm 0.99 \%$. Corresponding figures were obtained by analysing sera from cancer patients (15). In a followup period of $176.0 \pm 87.1$ days of 31 relapse-free patients after surgical removal of large bowel cancer, individual variations of $13.9 \pm 9.4 \%$ in serum sialyl transferase levels were found.

\section{Discussion}

The use of an insoluble glycoprotein acceptor-complex in serum sialyl transferase determinations as described here is more precise and more convenient than the classical assay using a soluble glycoprotein acceptor.
The "classical" method of serum sialyl transferase determinations, based on acid precipitation of glycoprotein, and removal of non-incorporated radioactivity by repeated washing, centrifugation and resuspension, has a low precision with a variation coefficient of $14-24 \%$. Another procedure (6), whereby non-incorporated radioactivity is removed by washing the acid precipitates on filter plates, results in slightly better precision (coefficient of variation $13-17 \%$ ). In general, acid denaturation of the serum proteins together with the NeuAc-accepting glycoprotein results in inhomogeneous and gummy precipitates. These materials adhere to the surfaces of the reaction tubes and of the filter discs, apparently embedding non-incorporated radioactivity. Even with lengthy washing procedures, the removal of soluble radioactivity tended to be erratic on our hands.

The use of an insoluble glycoprotein acceptor complex circumvents these difficulties. The resin used can easily and reproducibly be freed from non-incorporated radioactivity (coefficient of variation $3-7 \%)$. The published method using small ion exchange columns (13) is similarly convenient in this respect. However, a separate column is required for each determination, and the disposal of the used, radioactively contaminated columns is inconvenient. Recently another simplified procedure for the detection of serum sialyl transferase has been reported (16). Serum samples incubated with labeled nucleotide sugar and glycosylated endogenous acceptor molecules were absorbed to Con A Sepharose and quantitated by scintillation counting.

A distinct advantage of using an insoluble acceptor compared to the ion exchanger method is the fact that endogenous serum acceptors do not influence the assay system, being removed from the acceptorcomplex by washing. Thus, the measured radioactivity can be directly evaluated to $\mathrm{mol} / \mathrm{l}$ by subtraction of the blank (the amount of radioactivity which is unspecifically bound to the carrier) as a constant value. The possibility of dispensing with the correction for endogeneous sialyl group acceptors affords $50 \%$ savings in capacity needed for the serum sialyl transferase determinations.

It is hoped that the reproducibility and reliability of this serum sialyl transferase determination, as performed by the assay method described will contribute to further clinical studies regarding the significance of the tumour-associated increase in sialyl transferase levels in serum. 


\section{References}

1. Kessel, D. \& Allen, J. (1975) Cancer Res. 36, 670-672.

2. Henderson, M. \& Kessel, D. (1977) Cancer Res. 39, $1129-1131$.

3. Kessel, D., Samson, M. K. \& Shah, P. (1976) Cancer Res. $38,2132-2134$.

4. Herrmann, W. P. \& Gielen, W. (1979) Arch. Dermatol. Res. $265,321-329$.

5. Ganzinger, U. (1977) Wiener Klin. Wochenschr. 89, 594-597.

6. Bosmann, H. B. \& Hall, T. C. (1974) Proc. Natl. Acad. Sci. USA $71,1833-1837$.

7. Wilhelm, A., Berge, P. G. \& Schriewer, H. (1980) J. Clin. Chem. Clin. Biochem. 18, 271-273.

8. Spiro, R. G. (1960) J. Biol. Chem. 235, 2860-2867.

9. Morcll. A. G., Van Den Hamer, C. J. A., Scheinberg, H. I. \& Ashwell, G. (1966) J. Biol. Chem. 241, 3745-3749.
10. Cuatrecasas, P. \& Anfinsen, Ch. B. (1971) In: Methods in Enzymology Vol. XXII, (Jakoby, W. B., ed.) pp. 345-389, Academic Press, New York \& London.

11. Lowry, O. H., Rosebrough, N., Farr, L. \& Randall, R. (1951) J. Biol. Chem. 193, 265-275.

12. Koelsch, R., Lasch, J., Marquardt, I. \& Hanson, H. (1975) Analyt. Biochem. 66, 556-567.

13. Kessel, D., Chou, T. H. \& Allen, J. (1978) Eur. J. Biochem. $82,535-541$.

14. Cochran, W. G. \& Cox, G. M. (1957) Experimental Design, pp. 342-352, J. Wiley \& Sons, Inc., New York, London \& Signey.

15. Ganzinger, U. \& Deutsch, E. (1980) Cancer Res. 40, $1300-1304$.

16. Cerven, E., Ronquist, G., Rimsten, A. \& Agren, G. (1981) Upsala J. Med. Sci. 86, 237-247.

Dr. Ulrich Ganzinger

Sandoz Forschungsinstitut Ges.m.b.H.

Brunner Straße 59

A-1235 Wien 
